\title{
19. DISTRIBUTION OF CLAY FRACTION MINERALS IN MIOCENE THROUGH PLEISTOCENE TERRIGENOUS DEPOSITS OFF SOUTHERN CALIFORNIA AND BAJA CALIFORNIA, DEEP SEA DRILLING PROJECT LEG 631
}

\author{
M. A. Rateev, P. P. Timofeev, and V. I. Grechin, Geological Institute, \\ U.S.S.R. Academy of Sciences, Moscow, U.S.S.R.
}

This paper discusses the distribution of clay minerals and identification of their assemblages in relation to sedimentary facies encountered during DSDP Leg 63 drilling off southern California and Baja California. We also consider how these assemblages are determined by source areas and changes in general paleogeographic environments during different periods of sedimentation.

The minerals in the clay fraction $(<1 \mu \mathrm{m})$ were studied from cores recovered in the eastern Pacific along Southern California and Baja California. Sites 467 and 468 are located near the western edge of the southern California Continental Borderland. Sites 469, 470,471 , and 472 are located near the foot of the continental slope between $32^{\circ} 37.00^{\prime} \mathrm{N}$ and $23^{\circ} 00.35^{\prime} \mathrm{N}$. Site 473 is on the Rivera plate in the mouth of the Gulf of California, near the northern end of the Middle America trench (Fig. 1).

\section{SOME PECULIARITIES OF ENVIRONMENTS DURING FORMATION OF CLAY DEPOSITS}

The composition and structure of Miocene through Quaternary deposits recovered along the eastern marginal Pacific reflect a combination of three main inputs: biogenic (silicate and carbonate) accumulation, terrigenous sedimentation, and accumulation of pyroclastic material. The main types of sediments are represented by nannofossil and diatom oozes, clays, aleuritic clays, carbonate-silicate clays, sandy, aleurolite deposits, and rare volcanogenic sediments.

Proximity to the land and abundance of sandy-clay terrigenous material determined the predominance of terrigenous accumulation. These factors sometimes account for the high rates of sedimentation, particularly for the lower parts of the sequences at a majority of the holes (except Sites 470 and 472). Middle Miocene or upper Miocene deposits at Site 473 are represented by sandy-aleuritic-clay turbidites. Land-derived clay mineral assemblages include relatively stable varieties such as illite, chlorite, minor kaolinite, and mixed-layered montmorillonite-illite (M-I), as well as abundant smectites. The predominance of smectites in the composition of terrigenous clay mineral assemblages is rather typical

\footnotetext{
${ }^{1}$ Initial Reports of the Deep Sea Driling Project, Volume 63.
}

for Miocene through Quaternary deposits along the California margin. The abundance of smectite is probably related to a broad distribution of volcanogenic and volcanogenic-sedimentary formations that contain predominantly clay-size components.

Changes related to tectonic movements within the source province should affect the composition of assemblages of heavy-fraction minerals and detrital clay minerals. The middle Miocene sediments include only terrigenous, multiple redeposited material with monotonous assemblages of most stable heavy minerals: zircon, garnet, chromic spinel, and ore minerals. Near the end of the middle Miocene and the beginning of the late Miocene, volcanogenic deposits are more common. Pliocene deposits contain considerable proportions of debris weathered from metamorphic rocks exposed in seafloor outcrops in the southern California Continental Borderland. Common heavy minerals in this detritus include glauconite and minerals of the epidote-zoisite group.

Pyroclastic material also served as an important source for formation of authigenic clay minerals in the deposits studied. A considerable admixture of pyroclastic material (predominantly volcanic glass)-probably the products of subareal andesite volcanism - were found in many Miocene through Quaternary deposits. Fine interlayers of vitric ashes and tuffs with andesite-dacite composition were also found. The volcanogenic material is an important component only in middle to upper Miocene (Hole 467) or middle Miocene (Holes 468 and 469) deposits of the southern California Continental Borderland. The upper part of the sedimentary sections (down to the depth of about $200 \mathrm{~m}$ ) belongs to the zone of unaltered volcanic glass (Grechin et al., this volume). It is characterized by ashes not altered by secondary processes. Below this zone, all volcanic interlayers are diagenetically altered. Clay minerals and zeolites are formed by alteration of volcanic material. Authigenic clay minerals in the tuffs are represented by different structural varieties of smectites or mixed-layered components with a predominance of smectite layers in their structure. The same minerals are also developed in scattered pyroclastics and can be identified by X-ray diffraction analyses. However, the estimation of quantitative ratios between authigenic and terrigenous smectites is rather difficult. 


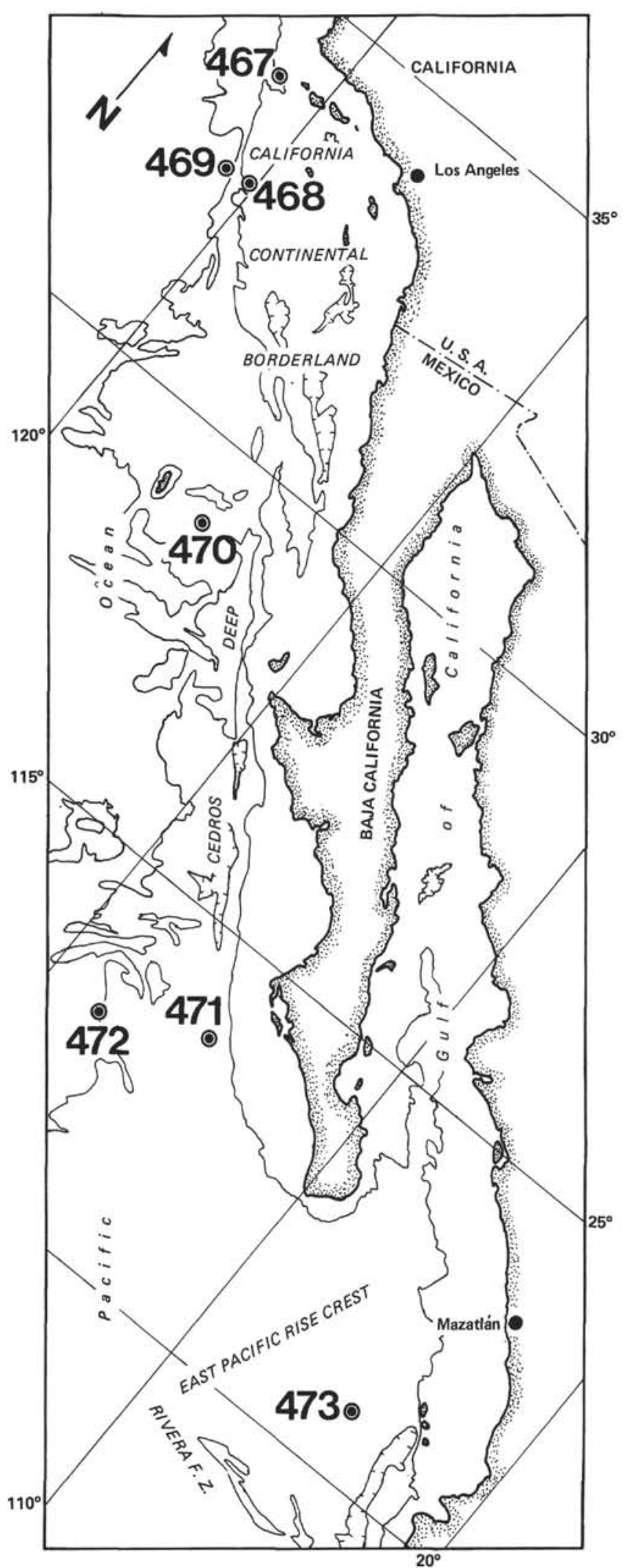

Figure 1. Location map of Leg 63 sites.

\section{X-RAY DIFFRACTION ANALYSES OF CLAY MINERALS}

The clay minerals were mainly studied by the standard X-ray diffraction method for the fraction $<1 \mu \mathrm{m}$. The diffractograms were obtained by the diffractometer "DRON-1" (USSR) using $\mathrm{CuK}_{\alpha}$ radiation generated at $34 \mathrm{kV}$ and $20 \mathrm{~mA}$. Scanning rates were $2^{\circ} 2 \theta / \mathrm{min}$. All samples were X-rayed in three states: (1) natural or air dry, (2) saturated by glycerine, and (3) heated at $550^{\circ} \mathrm{C}$. Besides illite, chlorite, and kaolinite, we described mixed-layered phases and structural varieties of minerals from the smectite group. We identified structural varieties of smectites on the basis of the correlation between intensities of basal peaks $d_{001}, d_{002}, d_{003}$ as well as the degree of resistance of these minerals to a $10 \%$ solution of $\mathrm{HCL}$ heated at $80^{\circ} \mathrm{C}$ for one hour. The volcanogenic rocks revealed the following varieties of smectites: dioctahedral $\mathrm{Al}$ - and $\mathrm{Al}, \mathrm{Fe}$-and $\mathrm{Ca}$-montmorillonites, $\mathrm{K}, \mathrm{Fe}$-montmorillonite, and trioctahedral Mg-montmorillonite. $\mathrm{Al}$ - and $\mathrm{Fe}$-montmorillonites and more frequently montmorillonite with $\mathrm{K}$ in the interlayers in the form of a green glauconitelike mineral (Holes 468 and $468 \mathrm{~B}$ ) were identified in clay mineral products of scattered vitroclastics in the rocks with mixed composition. The latter mineral has $d=13.4 \AA$ to $13.7 \AA$ in an airdry state, $d=16 \AA$ to $17 \AA$ after saturation with glycerine, and $d=9.93$ to $10.07 \AA$ after heating at $550^{\circ} \mathrm{C}$.

In those cases in which a mineral was identified as montmorillonite without indicating its structural varieties, it is synonomous with the group name smectite. Besides common ones we found iron varieties of illites. So-called "defect" chlorite, with $d=13.1 \AA$ to $13.8 \AA$ after heating at $550^{\circ} \mathrm{C}$ (or undergoing disintegration at the same temperature [Drits and Sakharov, 1976]), is frequently found among $\mathrm{Mg}-\mathrm{Fe}$ trioctahedral chlorites with $d=7.08 \AA, 4.70 \AA$, and $3.53 \AA$. Among mixedlayered minerals we identified two types; an intensively swelling montmorillonite-illite (M-I) close to smectite and an illite-montmorillonite (I-M) close to illite. Identification of mixed-layered minerals was made on the basis of well-known works by Reynolds (1968), Drits and Sakharov (1976), and Gradusov (1976).

An intensively swelling type of mixed-layered mineral (M-I) with disordered alternation of montmorillonitic layers was identified by diffraction maxima of $12.74 \AA$ up to $14.9 \AA$ in an untreated specimen, $18.3 \AA$ in a specimen saturated with glycerine, and $9.92 \AA$ in a specimen heated at $550^{\circ} \mathrm{C}$, with distinct assymetry of the peak towards small angles (Fig. 2). The second type of weakly swelling mixed-layered mineral (I-M) with disordered alternation between illite and montmorillonite layers revealed the following diffraction peaks: $10 \AA$ in an untreated specimen, $9.8 \AA$ to $9.89 \AA$ in a specimen saturated with glycerine, and $9.8 \AA$ after heating (Drits and Sakharov, 1976).

\section{DISTRIBUTION OF CLAY MINERALS AND THEIR ASSEMBLAGES IN SEDIMENTARY SEQUENCES OF LEG 63 SITES}

The distribution of clay minerals in sedimentary sequences is described from the bottom upward. All as- 


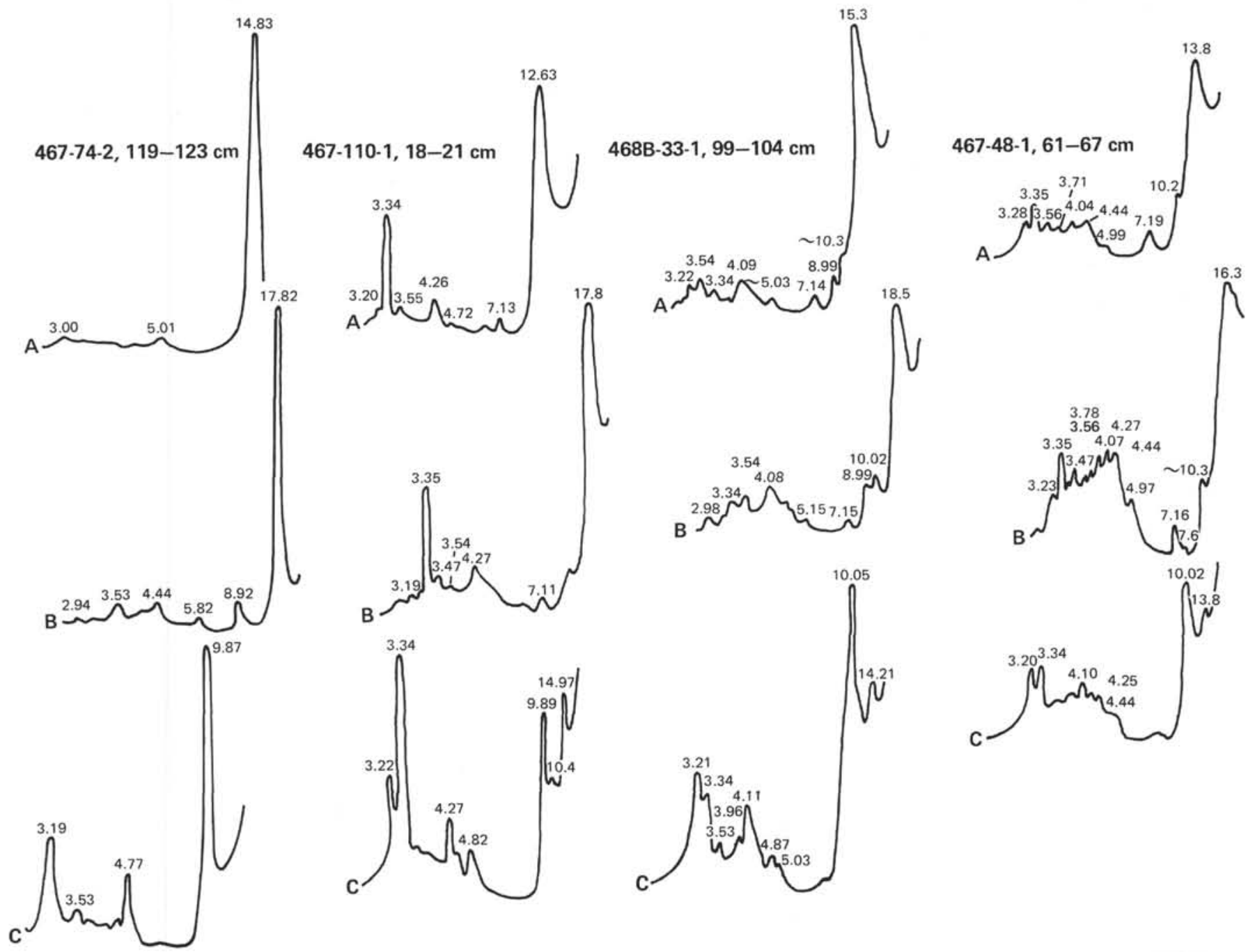

Figure 2. X-ray diffractograms of typical clay minerals-A. air dry; B. saturated with glycerine; and C. after heating at 550 ${ }^{\circ} \mathrm{C}$. (Sample $467-74-2$, $119-123 \mathrm{~cm}$ is a clay fraction composed of Al-montmorillonite, developed after tuffaceous material; Sample 467-110-1, 18-21 cm is composed of Al,Fe-montmorillonite with an admixture of illite and chlorite; Sample 467-48-1, 61-67 cm is K,Fe-montmorillonite with an admixture of illite and chlorite. Sample 468B-33-1, 99-104 cm is composed of montmorillonite, illite, and an admixture of chlorite and kaolinite.)

semblages of clay minerals are shown in Figure 3 by corresponding signs.

\section{Southern-California Continental Borderland}

\section{Hole 467}

The distribution of clay minerals in Hole 467 has the following features (Table 1).

Series 6 (Cores 86-110) is composed of middle to upper Miocene, poorly sorted sandy-silty-clay deposits frequently with carbonate cement (sometimes dolomitic) and minor authigenic barite and gypsum. The clay fraction in this series is represented by common montmorillonite and in single interlayers by unstable Fe-montmorillonite. These minerals are accompanied by a rather persistent admixture of chlorite and illite, more abundant in the lower part of the series.

Series 5 (Cores 74-84) comprises middle to upper Miocene, altered hyalotuffs with basaltic composition and nannofossil claystones. Assemblages of clay minerals from the tuffs are composed of an authigenic com- plex of minerals frequently without distinct admixture of detrital clay components. It shows a peculiar mixture of $\mathrm{Al}$-octahedral smectites and $\mathrm{Mg}$-trioctahedral smectites, partly chloritized. The authigenic smectites in tuff interlayers are often accompanied by mixed-layered minerals of chlorite-montmorillonite type (Ch-M).

Series 4 (Core 55-73) is made up of upper Miocene, calcareous claystones with single interlayers of silicate and nannofossil claystones. The clay fractions in this series contain montmorillonite, admixture of weakly swelling mixed-layered mineral of an illite-montmorillonite type (I-M), and traces of chlorite and opal C-T.

Series 3 (Cores 40-55) upper Miocene through lower Plicoene, poorly consolidated calcareous claystones, alternating with thinner interlayers of nannofossil and siliceous oozes. The series shows predominance of unstable montmorillonite with admixture of detrital minerals in the clay fraction: illite, chlorite, quartz, and feldspar.

Series 2 (Cores 10-40) is Pliocene nannofossil clay with interlayers of calcareous-clay and siliceous ooze. 
California Continental Borderland

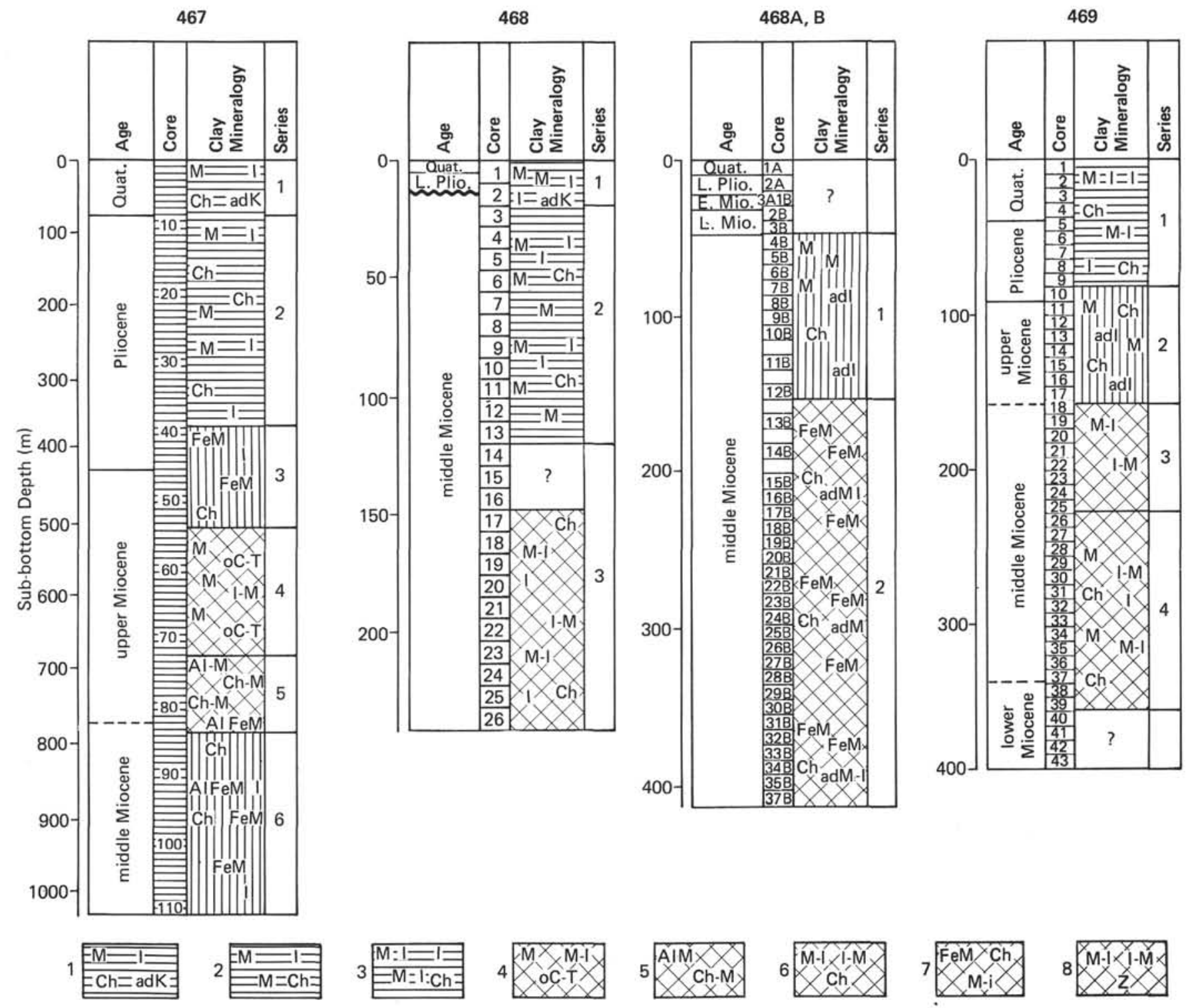

Figure 3. Scheme of distribution of clay mineral assemblages throughout the Leg 63 holes. (In the key to clay mineralogy, $1=$ polymineral montmorillonite (M) with illite (I), chlorite (Ch), and a small admixture of kaolinite $(\mathrm{ad} \mathrm{K}) ; 2=$ polymineral montmorillonite with illite and chlorite; 3 = polymineral with mixed-layered mineral (M-I), illite, and chlorite; $4=$ montmorillonite, mixed-layered (I-M), with opal C-T (o C-T); $5=$ Al-montmorillonite (Al-M) with mixed-layered mineral of a chlorite-montmorillonitic type (Ch-M); $6=$ mixed-layered with two types of minerals (M-I) and (I-M); 7 = Fe-montmorillonite (Fe-M) with chlorite and intensely swelling mixed-layered mineral $(\mathrm{M}-\mathrm{I})$ and opal C-T; $8=$ mixed-layered with two types of minerals (M-I) and (I-M) and zeolite; $9=$ montmorillonite with an admixture of chlorite, illite, and mixedlayered mineral (M-I); $10=$ montmorillonite with an admixture of illite, chlorite, and mixed-layered weakly swelling mineral $(\mathrm{I}-\mathrm{M}) ; 11=\mathrm{mont}$ morillonite with illite, chlorite, two types of mixed-layered minerals (M-I and I-M), and a small admixture of kaolinite; $12=\mathrm{Fe}-$ montmorillonite with an admixture of chlorite and illite; $13=$ montmorillonite with chlorite and small admixture of illite and zeolite; and $14=$ montmorillonite with chlorite and a small admixture of illite.)

The clay fraction of the series is predominantly composed of a polymineralic montmorillonitic assemblage with persistent admixture of detrital illites, chlorites, quartz, and feldspar.

Series 1 (Cores 1-11) is composed of Pleistocene greenish gray clay, and foraminifer-coccolith-spiculardiatomaceous oozes. The clay fraction of Series 1 is composed of montmorillonite with more considerable admixture of detrital illites, chlorite, kaolinite, and quartz than in underlying Series 2.

\section{Hole 468}

Clay minerals encountered at Hole 468 were divided into three series (Table 2).

Series 3 (Cores 17-26) is lower or middle Miocene diatom-nannofossil claystones, aleuritic or sandy claystones, and tuffs. The clay fraction of Series 3 is represented by montmorillonite (with potassium in interlayers), weakly swelling mixed-layered illite-montmorillonite (I-M), and admixture of chlorite. 
Western Continental Margin of Mexico
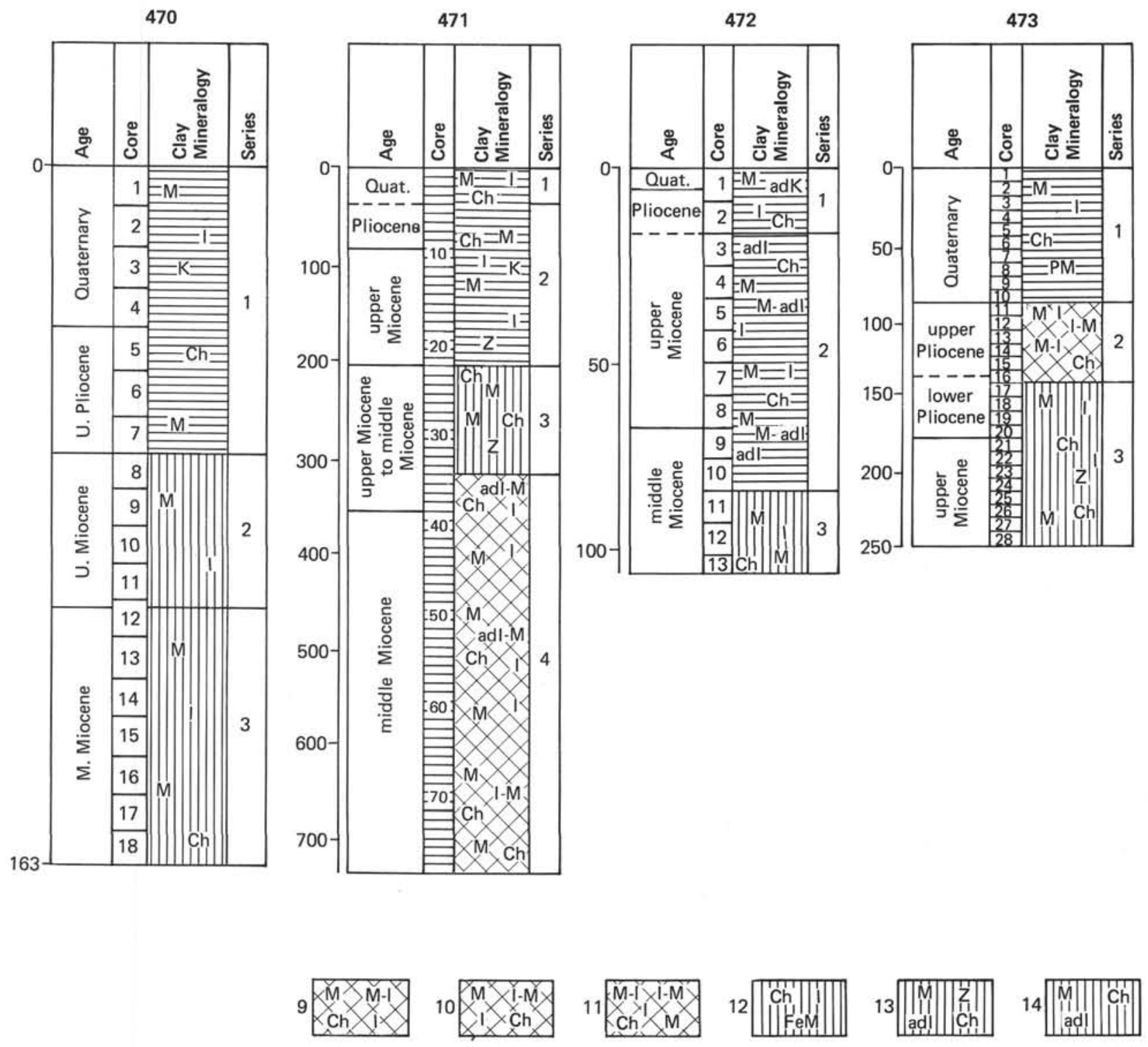

Figure 3. (Continued).

Series 2 (Cores 3-13) comprises middle Miocene nannofossil-diatom oozes with interlayers of sand, siltstone, and clay. The clay fraction $(<1 \mu \mathrm{m})$ has a polymineral composition with a predominance of montmorillonite and small admixtures of detrital minerals: illites, chlorite, quartz, and feldspar. More sandy interlayers contain $\mathrm{K}, \mathrm{Fe}$-montmorillonite in places.

Series 1 (Cores 1-2) is composed of Pliocene through Pleistocene foraminiferal and nannofossil oozes. The clay fraction is also predominantly composed of montmorillonite, however, the detrital admixture contains illite and chlorite and small amounts of kaolinite, quartz, and feldspar. Some interlayers have traces of $\mathrm{K}, \mathrm{Fe}-$ montmorillonite.

\section{Hole 468B}

Clay minerals of Hole 468B were divided into two series (Table 2).

Series 2 (Cores 13-37) comprises middle Miocene, calcareous siltstones, claystones with interlayers of andesite-dacitic breccia, pumiceous lithoclastic tuffs, and volcaniclastic sandstones. The clay fraction has a predominance of $\mathrm{Fe}$-montmorillonite with admixture of chlorite and intensely swelling, mixed-layered mineral (M-I).

Series 1 (Cores 4-12) is middle Miocene, alternating nannofossil oozes and diatom-nannofossil oozes with interlayers of detrital sands and aleuritic clayey sedi- 
Table 1. Clay minerals and their assemblages in Miocene through Quaternary sediments from Hole 467.

\begin{tabular}{|c|c|c|c|c|}
\hline Age & $\begin{array}{l}\text { Sample } \\
\text { (interval in } \mathrm{cm} \text { ) }\end{array}$ & $\begin{array}{l}\text { Lithologic Type of } \\
\text { Sediments }\end{array}$ & $\begin{array}{l}\text { Mineralogical Composition of } \\
\text { Clay Fraction }(<1 \mu \mathrm{m})\end{array}$ & $\begin{array}{l}\text { Assemblages of Clay and } \\
\text { Accessory Minerals }\end{array}$ \\
\hline \multirow{2}{*}{$\begin{array}{l}\text { Quater- } \\
\text { nary }\end{array}$} & $2-3,37-38$ & Aleuritic clay & $\begin{array}{l}\text { Fe-montmorillonite, illite, admixture of } \\
\text { chlorite, kaolinite, quartz, and feldspar }\end{array}$ & \multirow[t]{2}{*}{$\begin{array}{l}\text { Polymineral with } \mathrm{Fe} \text {-montmorillonite, illite, } \\
\text { chlorite, and small admixture of kaolinite }\end{array}$} \\
\hline & $8-5,45-50$ & $\begin{array}{l}\text { Nannofossil diatomic } \\
\text { clays }\end{array}$ & $\begin{array}{l}\text { Fe-montmorillonite, illite, admixture of } \\
\text { chlorite, kaolinite, quartz, and feldspar }\end{array}$ & \\
\hline \multirow{5}{*}{ Pliocene } & $19-5,110-115$ & Diatom clays & Montmorillonite, illite, small admixture & \multirow{4}{*}{$\begin{array}{l}\text { Polymineral montmorillonite with admixture } \\
\text { of illite, chlorite, traces of kaolinite (with } \\
\text { Fe-montmorillonite in some interlayers) }\end{array}$} \\
\hline & $30-2,110-114$ & Clays & $\begin{array}{l}\text { Fe-montmorillonite, illite, chlorite, } \\
\text { admixture of quartz and feldspar }\end{array}$ & \\
\hline & $40-1,16-20$ & $\begin{array}{l}\text { Nannofossil, aleuritic } \\
\text { clays }\end{array}$ & $\begin{array}{l}\text { Montmorillonite, illite, small admixture } \\
\text { of kaolinite, quartz, and feldspar }\end{array}$ & \\
\hline & $40-3,16-20$ & $\begin{array}{l}\text { Nannofossil, aleuritic } \\
\text { clays }\end{array}$ & $\begin{array}{l}\text { Montmorillonite, illite, small admixture } \\
\text { of kaolinite, quartz, and feldspar }\end{array}$ & \\
\hline & $48-1,61-67$ & Clays & \multirow{2}{*}{$\begin{array}{l}\text { Fe-montmorillonite, illite, chlorite, } \\
\text { admixture of quartz and feldspar } \\
\text { Fe-montmorillonite, illite, chlorite, } \\
\text { admixture of quartz and feldspar }\end{array}$} & \multirow{2}{*}{$\begin{array}{l}\text { Fe-montmorillonite with small admixture } \\
\text { of illite and chlorite }\end{array}$} \\
\hline \multirow{10}{*}{$\begin{array}{c}\text { late } \\
\text { Miocene }\end{array}$} & $52-1,32-34$ & Clays & & \\
\hline & $57-1,104-108$ & $\begin{array}{l}\text { Calcareous aleuritic } \\
\text { claystones }\end{array}$ & Al, Fe-montmorillonite, small admixture & \multirow[b]{2}{*}{$\begin{array}{l}\text { Minerals of silica with montmorillonite and } \\
\text { admixture of mixed-layered minerals (M-I) }\end{array}$} \\
\hline & $71-1,35-38$ & $\begin{array}{l}\text { claystones } \\
\text { Calcareous claystones }\end{array}$ & $\begin{array}{l}\text { Opal C-T, small admixture of montmo- } \\
\text { rillonite and mixed-layered mineral (M-I), } \\
\text { traces of chlorite }\end{array}$ & \\
\hline & $74-2,98-100$ & $\begin{array}{l}\text { Intensively altered } \\
\text { hyalotuff }\end{array}$ & $\begin{array}{l}\text { Al-montmorillonite (beidellite- } \\
\text { montmorillonite) }\end{array}$ & \multirow{7}{*}{$\begin{array}{l}\text { Authigenic } \mathrm{Mg}, \mathrm{Fe} \text {-montmorillonite at the } \\
\text { initial stage of chloritization, } \\
\mathrm{Al} \text {-montmorillonite }\end{array}$} \\
\hline & $74-2,119-123$ & $\begin{array}{l}\text { Intensively altered } \\
\text { hyalotuff }\end{array}$ & $\begin{array}{l}\text { Al-montmorillonite (beidellite- } \\
\text { montmorillonite) }\end{array}$ & \\
\hline & $80-2,16-20$ & Altered hyalotuff & $\begin{array}{l}\text { Mg, Fe-montmorillonite, Al- } \\
\text { montmorillonite, small admixture of } \\
\text { chlorite-montmorillonite }\end{array}$ & \\
\hline & $82-1,114-118$ & Altered hyalotuff & $\begin{array}{l}\text { Mg, Fe-montmorillonite, Al- } \\
\text { montmorillonite, small admixture of } \\
\text { chlorite-montmorillonite }\end{array}$ & \\
\hline & $82-1,118-120$ & Altered hyalotuff & $\begin{array}{l}\mathrm{Mg} \text {, Fe-montmorillonite, } \mathrm{Al} \text { - } \\
\text { montmorillonite, small admixture of } \\
\text { chlorite-montmorillonite }\end{array}$ & \\
\hline & $83-3,83-85$ & Tuff & $\begin{array}{l}\mathrm{Mg}, \mathrm{Fe} \text {-mixed-layered mineral (M-1), } \\
\text { Al-montmorillonite, chlorite- } \\
\text { montmorillonite }\end{array}$ & \\
\hline & $84-1,31-35$ & Tuff & $\begin{array}{l}\text { Mg, Fe-mixed-layered mineral (M-I), } \\
\text { Al-montmorillonite, chlorite- } \\
\text { montmorillonite }\end{array}$ & \\
\hline \multirow{8}{*}{$\begin{array}{l}\text { middle } \\
\text { Miocene }\end{array}$} & $86-3,146-150$ & $\begin{array}{l}\text { Calcareous nanno- } \\
\text { fossil claystones }\end{array}$ & $\begin{array}{l}\text { Montmorillonitic, mixed-layered mineral } \\
\text { (M-I), small admixture of chlorite }\end{array}$ & \multirow{8}{*}{$\begin{array}{l}\mathrm{Al} \text { and } \mathrm{Al}, \mathrm{Fe} \text {-montmorillonite with } \\
\text { Fe-montmorillonite in some interlayers } \\
\text { (the lower part has a more distinct } \\
\text { admixture of detrital minerals: } \\
\text { illite, chlorite, and quartz) }\end{array}$} \\
\hline & $90-1,32-37$ & Nannofossil claystones & $\begin{array}{l}\text { Montmorillonitic, mixed-layered mineral } \\
\text { (M-I), small admixture of chlorite }\end{array}$ & \\
\hline & $92-1,67-71$ & Clay chalk & $\begin{array}{l}\text { Quartz, small admixture of } \\
\text { montmorillonite and illite }\end{array}$ & \\
\hline & $96-1,95-98$ & $\begin{array}{l}\text { Clay, nannofossil } \\
\text { claystone }\end{array}$ & $\begin{array}{l}\text { Al, Fe-montmorillonite, admixture of } \\
\text { quartz }\end{array}$ & \\
\hline & $101-1,123-127$ & $\begin{array}{l}\text { Calcareous, nanno- } \\
\text { fossil claystone }\end{array}$ & $\begin{array}{l}\text { Al, Fe-montmorillonite, admixture of } \\
\text { quartz }\end{array}$ & \\
\hline & $104-2,25-28$ & $\begin{array}{l}\text { Calcareous, aleuritic } \\
\text { claystone }\end{array}$ & $\begin{array}{l}\text { Fe-montmorillonite, illite, chlorite, and } \\
\text { quartz }\end{array}$ & \\
\hline & $107-1,1-4$ & Aleuritic claystone & $\begin{array}{l}\text { Montmorillonite, illite, chlorite, and } \\
\text { quartz }\end{array}$ & \\
\hline & $110-1,18-21$ & $\begin{array}{l}\text { Calcareous, aleuritic } \\
\text { claystone }\end{array}$ & $\begin{array}{l}\text { Al, Fe-montmorillonite, small admixture } \\
\text { of illite, chlorite, and quartz }\end{array}$ & \\
\hline
\end{tabular}

ments in the lower part of the sequence. Its clay fraction is predominantly represented by montmorillonite (sometimes including $\mathrm{K}, \mathrm{Fe}$-montmorillonite) with admixture of chlorite and illite.

\section{Off the Continental Slope (between $32^{\circ}$ and $23^{\circ} \mathrm{N}$ )}

The sediments of this region have interlayers of vitric ashes and scattered volcaniclastics with andesitic and andesitic-dacitic compositions. Postdepositional alteration of this volcaniclastic material leads to formation of dioctahedral, stable, common $\mathrm{Al}$-montmorillonites (with admixture of $\mathrm{Mg}^{2+}$ in octahedral positions).

\section{Hole 469}

Clay minerals in Hole 469 were divided into four series (Table 2).

Series 4 (Cores 26-38) is lower middle Miocene aleuritic claystones with subordinate interlayers of pumiceous lithoclastic tuffs, volcanic sandstones, porcellanites, nannofossil claystones, chalk, and siliceous limestones. The clay fraction is mainly composed of montmorillonite with admixture of illite, chlorite, and mixed-layered intensely swelling mineral (M-I) in some interlayers.

Series 3 (Cores 18-25) is middle Miocene nannofossil oozes and diatom-nannofossil oozes. The clay fraction is represented by two types of mixed-layered minerals (M-I and I-M) with admixture of zeolite.

Series 2 (Cores 10-17) is upper Miocene clayey nannofossil oozes with interlayers of diatom-nannofossil oozes. The clay fraction is predominantly composed of montmorillonite (partially with potassium in interlayers) with chlorite and small admixture of illite.

Series 1 (Cores 1-9) is composed of Pliocene through Pleistocene foraminifer-nannofossil clays (Cores 5-9) enriched by ash material upsection (Cores 1-4). The clay fraction is composed of a polymineral assemblage with predominance of intensely swelling mixed-layered mineral (M-I) close to smectite with admixture of illite and chlorite. 
Table 2. Clay minerals and their assemblages in Miocene through Pliocene sediments, DSDP Leg 63.

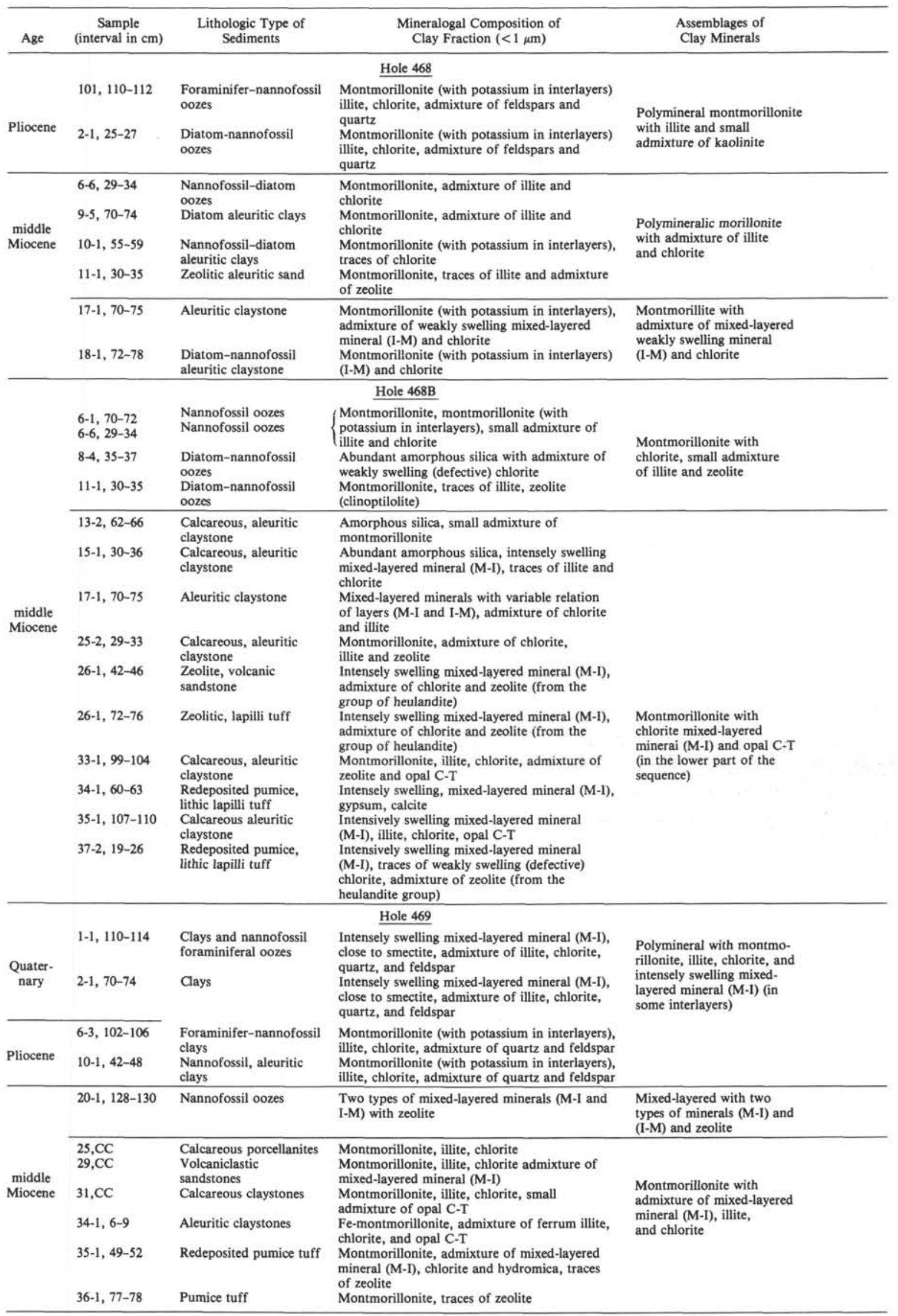




\section{Hole 470}

Clay minerals in Hole 470 were divided into three series (Table 3).

Series 3 (Cores 12-15) is middle Miocene diatomaceous, aleuritic clays and nannofossil oozes. The clay fraction is predominantly composed of montmorillonite (with $\mathrm{K}$ and $\mathrm{Na}$ in interlayers), with admixture of illite, chlorite, feldspar, and quartz.

Series 2 (Cores 8-11) consists of upper Miocene diatomaceous, aleuritic clays. The clay fraction is predominantly composed of montmorillonite with admixture of illite, chlorite, quartz, and feldspar in some interlayers.

Series 1 (Cores 1-7) comprises upper Pliocene through Pleistocene aleuritic and nannofossil clays. The clay fraction is predominantly composed of montmorillonite (with $\mathrm{K}$ and $\mathrm{Na}$ in interlayers) with small admixture of illite and chlorite and rarely kaolinite, quartz, and feldspar.

\section{Hole 471}

Clay minerals in Hole 471 were divided into four series (Table 4).

Series 4 (Cores 35-78) consists of middle Miocene bioturbated claystones with thin interlayers of calcareous sandstones (less abundant in the base) and several interlayers of clayey limestones and altered vitritic tuffs. The clay fraction is composed of montmorillonite (frequently with $\mathrm{K}$ in interlayers) with admixture of illite, chlorite, and mixed-layered weakly swelling mineral (I-M), quartz, and feldspar.

Series 3 (Cores 22-34) is upper Miocene porcellanites and porcelaneous, aleuritic claystones with cherts and several interlayers of clayey limestones. The clay fraction is predominantly composed of montmorillonite (partially with $\mathrm{K}$ in interlayers) with admixture of illite, chlorite, zeolite, and opal C-T.

Series 2 (Cores 4-22) is composed of upper Miocene through Pliocene diatomaceous aleuritic clays and clayey-diatomaceous oozes. The clay fraction is composed of a polymineral assemblage with montmorillonite, illite, and chlorite, with some admixture of kaolinite, quartz, and feldspar.
Series 1 (Cores 1-3) is Pleistocene nannofossil clays. The clay fraction has polymineral composition with montmorillonite, illite, and chlorite.

\section{Hole 472}

Clay minerals in Hole 472 were divided into three series (Table 5).

Series 3 (Cores 11-13) is middle Miocene diatomaceous oozes and nannofossil clays. The clay fraction is composed of montmorillonite with small admixture of illite and chlorite.

Series 2 (Cores 3-10) is middle upper Miocene, clayey-diatomaceous oozes and siliceous pelagic clays. The clay fraction has a polymineral composition with montmorillonite, admixture of illite, chlorite, quartz, and feldspar.

Series 1 (Cores 1-2) is Pliocene through Pleistocene, brown pelagic clays with subordinate amount of greenish gray pelagic clays. The clay fraction has a polymineral composition with montmorillonite, illite, admixture of kaolinite, small admixture of chlorite, quartz, and feldspar. Montmorillonite in all series frequently contains $\mathrm{K}$ in interlayers.

\section{The Mouth of the Gulf of California}

\section{Hole 473}

Distribution of Hole 473 clay minerals has the following succession (Table 5).

Series 3 (Cores 17-28) is upper Miocene through lower Pliocene claystones and interbedded aleuritic quartz sandstones. The clay fraction is composed of montmorillonite with small admixture of chlorite, illite, and opal C-T. The montmorillonite frequently contains $\mathrm{K}$ in interlayers.

Series 2 (Cores 11-16) contains upper Pliocene, terrigenous clays with a subordinate amount of aleuritic and nannofossil clays. The clay fraction is composed of montmorillonite, illite, and chlorite in places with small admixture of mixed-layered (M-I) and (I-M) minerals or kaolinite.

Series 1 (Cores 1-10) is Pleistocene clays with small admixture of ash material. The clay fraction has a polymineral composition. It is composed of montmoril-

Table 3. Clay minerals and their assemblages in Miocene through Quaternary sediments, Hole 470.

\begin{tabular}{|c|c|c|c|c|}
\hline Age & $\begin{array}{l}\text { Sample } \\
\text { (interval in } \mathrm{cm} \text { ) }\end{array}$ & $\begin{array}{l}\text { Lithological Type } \\
\text { of Sediments }\end{array}$ & $\begin{array}{l}\text { Mineralogical Composition of } \\
\text { Clay Fractions }(<1 \mu \mathrm{m})\end{array}$ & $\begin{array}{l}\text { Assemblages of Clay and } \\
\text { Accessory Minerals }\end{array}$ \\
\hline \multirow[t]{2}{*}{ Quaternary } & $1-3,92-96$ & Aleuritic clay & $\begin{array}{l}\text { Montmorillonite (with } \mathrm{K} \text { and } \mathrm{Na} \text { in interlayers), } \\
\text { considerable admixture of illite and chlorite }\end{array}$ & \multirow{3}{*}{$\begin{array}{l}\text { Polymineral montmorillonite } \\
\text { with admixture of illite, } \\
\text { chlorite, traces of kaolinite, } \\
\text { quartz, and feldspar }\end{array}$} \\
\hline & $2-3,77-82$ & Aleuritic clay & $\begin{array}{l}\text { Montmorillonite (with } \mathrm{K} \text { and } \mathrm{Na} \text { in interlayers), } \\
\text { small admixture of illite and chlorite }\end{array}$ & \\
\hline Pliocene & $5-1,108-113$ & Nannofossil clays & $\begin{array}{l}\text { Montmorillonite (with } \mathrm{K} \text { and } \mathrm{Na} \text { in interlayers), } \\
\text { considerable admixture of illite, chlorite, } \\
\text { quartz, and feldspars }\end{array}$ & \\
\hline \multirow[t]{2}{*}{$\begin{array}{c}\text { late } \\
\text { Miocene }\end{array}$} & & $\begin{array}{l}\text { Diatom aleuritic } \\
\text { clays }\end{array}$ & $\begin{array}{l}\text { Montmorillonite (with considerable amount of } \\
\mathrm{K} \text { in interlayers) }\end{array}$ & \multirow{2}{*}{$\begin{array}{l}\text { Montmorillonite with small } \\
\text { admixture of illite, quartz, } \\
\text { and feldspar in some } \\
\text { interlayers }\end{array}$} \\
\hline & $10-2,21-25$ & $\begin{array}{l}\text { Diatom aleuritic } \\
\text { clays }\end{array}$ & $\begin{array}{l}\text { Montmorillonite finely dispersed, with small } \\
\text { admixture of illite, quartz, and feldspars }\end{array}$ & \\
\hline \multirow[t]{2}{*}{$\begin{array}{l}\text { middle } \\
\text { Miocene }\end{array}$} & $12-3,120-125$ & $\begin{array}{l}\text { Diatom aleuritic } \\
\text { clays }\end{array}$ & $\begin{array}{l}\text { Montmorillonite (with } \mathrm{K} \text { and } \mathrm{Na} \text { in interlayers), } \\
\text { admixture of hydromica, chlorite, quartz, and } \\
\text { feldspars }\end{array}$ & \multirow[t]{2}{*}{$\begin{array}{l}\text { Montmorillonite with } \\
\text { admixture of illite, chlorite, } \\
\text { feldspar, and quartz }\end{array}$} \\
\hline & $15-1,80-85$ & $\begin{array}{l}\text { Diatom nanno- } \\
\text { fossil oozes }\end{array}$ & $\begin{array}{l}\text { Montmorillonite (with } \mathrm{K} \text { and } \mathrm{Na} \text { in interlayers), } \\
\text { small admixture of chlorite, illite, and feldspars }\end{array}$ & \\
\hline
\end{tabular}


Table 4. Clay minerals and their assemblages in Miocene through Pliocene sediments, Hole 471.

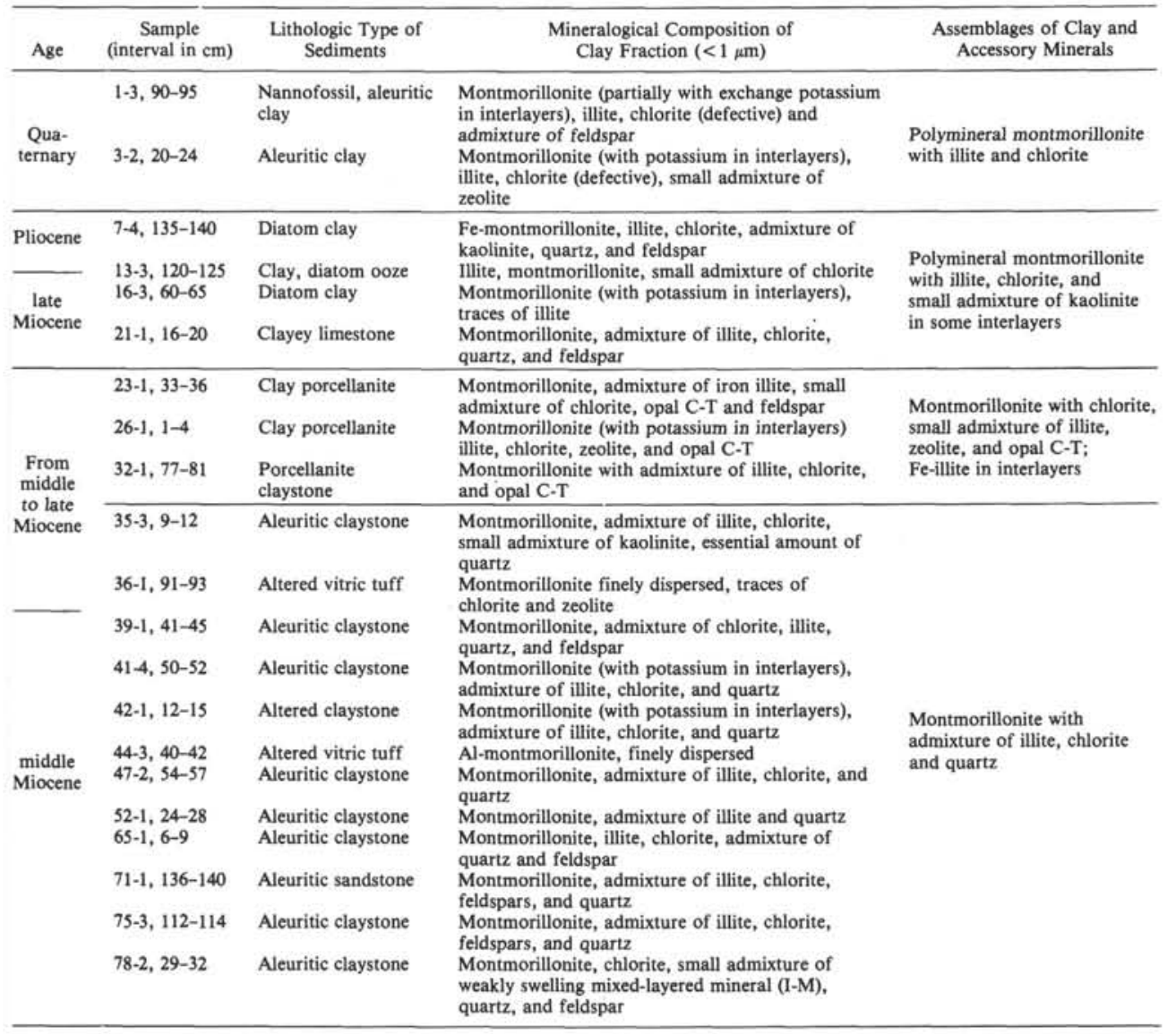

lonite with admixture of illite, chlorite, quartz, and feldspar.

\section{CONCLUSION}

Middle Miocene through Quaternary sediments encountered in southern California Continental Borderland and the western continental margin of Mexico are principally composed of siliceous and calcareous biogenic material, clay, and admixtures of aleuritic and fine, sandy, terrigenous, or tuffaceous material. Thicknesses of sedimentary sequences vary in the studied region from 150 up to 1000 meters.

The upper parts of sedimentary sections, approximately to the depth of 200 meters (and in Hole 467, up to $500 \mathrm{~m}$ ), are represented predominantly by unconsolidated or poorly consolidated oozes. The interlayers of volcanic ashes here do not show any features of secondary alteration such as the formation of authigenous clay minerals.

The clay fraction of these deposits is terrigenous and polymineralic. These minerals include a complex association of redeposited detrital minerals from the montmorillonite (smectite) group, and to a lesser extent, illite (with a different degree of degradation), chlorites (Fe$\mathrm{Mg}$ trioctahedral type), and rarely kaolinite. All clay minerals may have been derived from land.

The predominance of the smectitic component is a mineralogical peculiarity of these deposits; illites and chlorites are found as an admixture. Smectites occur in practically all sequences penetrated by Leg 63 holes, as in Pliocene sediments of the Panama basin (Rateev et al., in press), and can be considered as a background terrigenous component against which the Leg 63 deposits were formed. The presence of such smectitic background may indicate persistent subaerial and submarine volcanic sources.

In lower parts of the sedimentary sequences, below 200 meters on the average (in Hole 467, below $500 \mathrm{~m}$ ), the tuffaceous material (including both separate tuff interlayers and scattered volcaniclastics) is partially or completely transformed into clay or zeolitic mineral. Smectite here is the main authigenic mineral. However, its structural features vary depending on petrographic composition of the source rocks. For example, the basaltic hyalotuffs are altered to smectites with high $\mathrm{Fe}$ and $\mathrm{Mg}$ content in association with a small amount of chlorite in the form of a mixed-layered chlorite-montmorillonitic (Ch-M) mineral. Only in one case (Sample 467-74-2, 96-100 cm) was almost monomineralic smectite of the beidellitic type formed (with replacement of $\mathrm{Si}$ atoms in tetrahedral layers), possibly after the basaltic tuff.

Pumiceous and vitroclastic tuffs of more acid andesitic and dacitic composition also have altered to montmorillonites or intensely swelling, mixed-layered montmorillonite-illite (M-I) minerals of the type with a small 
Table 5. Clay minerals and their assemblages in Miocene through Pliocene sediments, DSDP Leg 63.

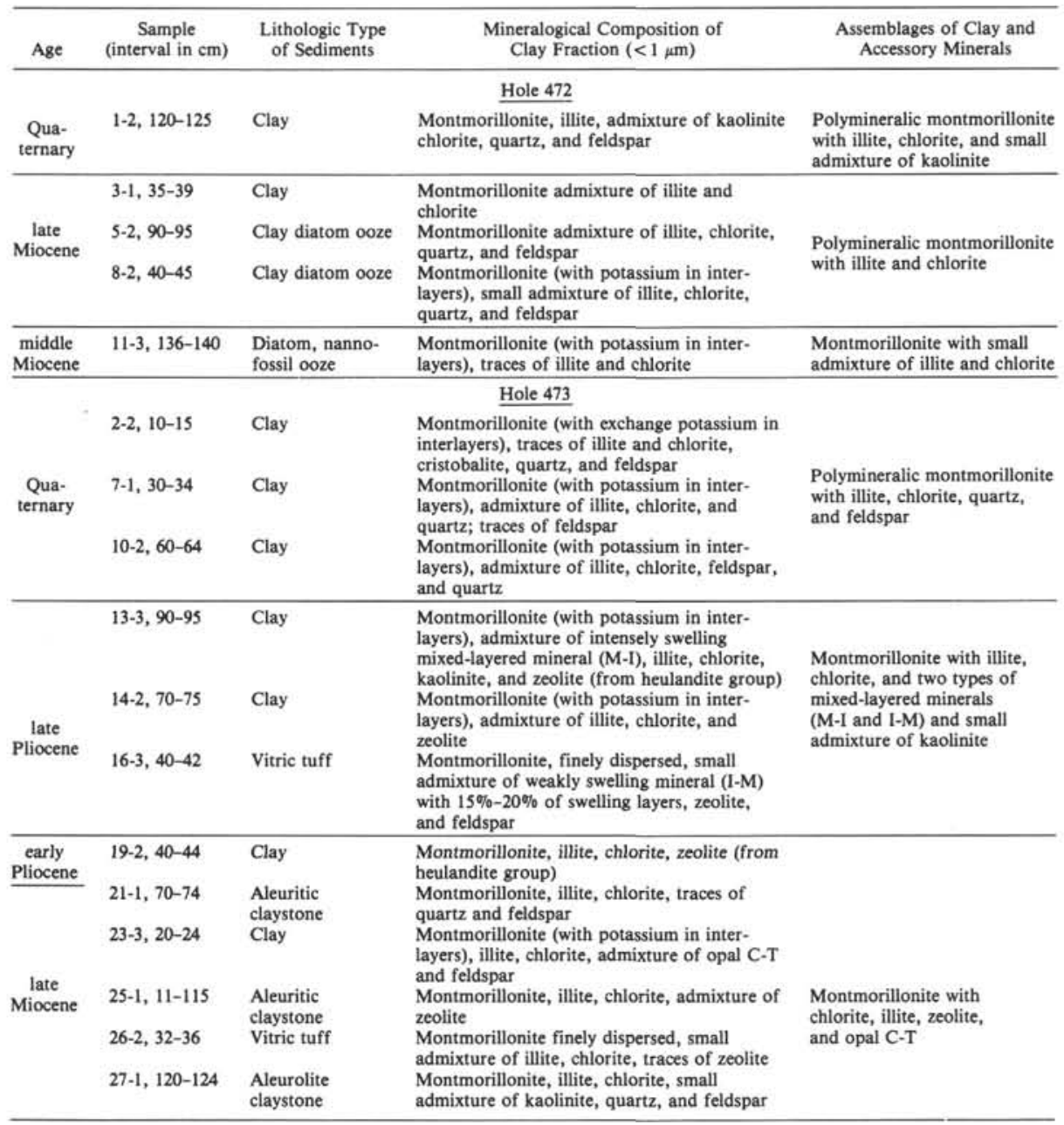

proportion of mica layers. We relate the small admixture of illite and chlorite in the clay fraction of these rocks with some portion of terrigenous material.

Besides clay material formed at the expense of subaerial pyroclastics, a considerable proportion of alteration products might be derived from submarine volcanic rocks. The clay products resulting from secondary alteration of igneous rocks in the Leg 63 area are described by Grechin et al. (this volume). They show that secondary alterations of abyssal tholeitic hyalobasalts and dolerites predominantly led to formation of smectites ( $\mathrm{Fe}$ and $\mathrm{Mg}-\mathrm{Fe}$ types) and intensely swelling mixed-layered minerals of montmorillonite-illite type (M-I), frequently with a ratio of about 85:15. Sometimes they are mixed with so-called "defective" chlorites and mixed-layered chlorite-montmorillonitic type minerals (Ch-M). All these minerals could enter the clay constituent of the Miocene through Pliocene sedimentary deposits. The absence of illite in the secondary minerals of basalts confirmed our conclusion that this clay mineral is probably land-derived and not authigenic.

In the lower part of the middle to upper Miocene sequences, clays derived from the land or from subaerial and underwater volcanism also occur with a constituent of authigenic smectites, formed in situ by diagenetic transformations of ash-tuffaceous material. However, the similarity between a number of clay mineral assemblages, abundant both in the lower and upper parts of the sequences, shows that the proportion of authigenic smectites in the terrigenous deposits as a whole is not considerable.

The minor alteration of the studied terrigenous rocks and small volume of authigenic smectite formation after tuffaceous material here result from relatively shallow burial (maximum up to $1000 \mathrm{~m}$ ) of sedimentary matter. Burial diagenesis may also account for all variations in diagenetic clay mineral assemblages in a variety of lithofacies encountered during Leg 63 drilling.

These conclusions are in good agreement with the results of Hein et al. (1979) on distribution of clay minerals throughout the sequence of Test Well-OCS CAL 78164, No. 1 in the external part of the continental shelf off Southern California $(19 \mathrm{~km}$ to the west of Point Conception). In this test well, the authors revealed considerable alterations of clay minerals at a depth of about 8600 feet $(2866 \mathrm{~m})$. These alterations affected mixed-layered smectite-illite mineral, which showed a decrease in swelling smectitic layers and corresponding increase in illitic structural packets, below this depth. The $\mathrm{K}$ required for illite formation may have 
been derived from K-feldspars. Perry and Hower (1970; 1972) show that the decrease of swelling layers down to $30 \%$ to $40 \%$ takes place under a temperature range of $95^{\circ} \mathrm{C}$ to $100^{\circ} \mathrm{C}$ and is accompanied by an increase of order in the mixed-layered phase.

We think that alteration in the zone of relatively deeper burial (Müller, 1967) occurs in already partially consolidated ("ready") rock under the effect of gravitation (i.e., consolidation, partial increase of temperature, recrystallization, solid-state reactions [Kossovskaya, and Shutov, 1963]). In contrast to this, diagenetic alteration in the zone of "shallow burial" takes place in poorly consolidated oozes in concert with abundant interstitial waters (Strachov, 1960).

Above the depth of 2866 meters, Hein et al. (1979) identified a number of intervals by a change in percentage of separate clay minerals, relating them to a change of source areas. Small changes include some increase of kaolinite within the interval of 6100 to 8800 feet (1859$2682 \mathrm{~m}$ ) together with an increase of quartz and feldspar, as well as pronounced increase of illite (within the interval of 6700-7400 feet-2042-2255 m). Hein et al. think that the intervals of greater quantitative variations of clay minerals, which have stratigraphic significance, can also reflect the change in physical-geographical environments of source areas. Thus, in their opinion, considerable decrease or increase in the depth of sedimentation can determine the scale of mineralogical alterations.

\section{REFERENCES}

Bramlette, M. N., 1946. Monterey formation of California and the origin of its siliceous rocks. Geol. Surv. Prof. Paper 212.

Drits, V. A., and Sakharov, B. A., 1976. X-ray structural analysis of mixed-layer minerals. Tr. Akad. Nauk SSR Inst. Geol., 295:101253.

Gradusov, B. P., 1976. Minerals with Mixed-layer Structure in Soils: Moscow (Nauka).

Hein, J. R., Vanek, E., and Allen, M. A., 1979. X-ray mineralogy and diagenesis. Geologic studies of the Point Conception Deep Stratigraphic Test Well OCS CAL 78164, No. 1. In Cook, H. E. (Ed.), USGS Open File Rep. 79-1218, pp. 79-96.

Khvorova, I. V., 1968. Deposition of silica in geosynclinal areas of the past time. Sedimentation and Ore Deposits of the Ancient Volcanic Regions, Transactions Geological Institute (Vol. 195): Moscow (Nauka).

Kossovskaya, A. G., and Schutov, V. A., 1963. Facies regional epigenesis and metagenesis. Izv. Akad. Nauk. SSR Geol., 7:3-18.

Müller, G., 1967. Diagenesis in sediments. Developments in Sedimentology: Amsterdam (Elsevier Publishing Co.), 8:127-178.

Perry, E. A., and Hower, J., 1970. Burial diagenesis in Gulf Coast pelitic sediments. Clays Clay Miner., 18:165-175.

1972. Late-stage dehydration in deeply buried pelagic sediments. Am. Assoc. Pet. Geol. Bull., 56:2013-2021.

Rateev, M. A., Timofeev, P. P., and Rengarten, N. V., in press. Minerals of the clay fraction in Pliocene-Quaternary sediments of the East Equatorial Pacific, Leg 54 DSDP. In Hekinian, R., Rosendahl, B. R., Init. Repts. DSDP, 54: Washington (U.S. Govt. Printing Office), 307-318.

Reynolds, R. G., 1968. The effect of particle size on apparent lattice spacing. Acta Crystallogr. 24:319-320.

Strachov, N. M., 1960. Theory of the Lithogenesis: Moscow (Nauka). 